\title{
Primary Spinal Epidural Lymphoma: A Case Report
}

\author{
Primer Spinal Epidural Lenfoma: Olgu Sunumu

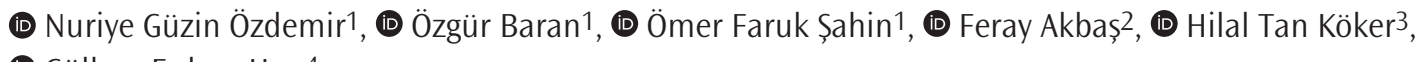 \\ (D) Gülben Erdem Huq ${ }^{4}$
}

1University of Health Sciences Turkey, İstanbul Training and Research Hospital, Clinic of Neurosurgery, İstanbul, Turkey

2University of Health Sciences Turkey, İstanbul Training and Research Hospital, Clinic of Internal Medicine, İstanbul, Turkey

3University of Health Sciences Turkey, İstanbul Training and Research Hospital, Clinic of Hematology, i̇stanbul, Turkey

${ }^{4}$ University of Health Sciences Turkey, İstanbul Training and Research Hospital, Clinic of Pathology, İstanbul, Turkey

\begin{abstract}
Primary spinal epidural lymphomas are the disorders that are very rarely seen. Spinal cord compression requires surgical decompression after which chemotherapy is initiated. A 46-yearold man presented with back and leg pain with progressive weakness of the lower extremities. Magnetic resonance imaging showed an extradural mass lesion compressing the cord anterolaterally and posteriorly at T-11. Surgical decompression with tumoural resection was performed. The pathological examination was reported as diffuse large B-cell lymphoma with germinal centre phenotype. Chemotherapy was initiated by the haematology clinic, and the patient was referred to physical therapy unit for his minimal paraparesis. After the operation, no pathologic involvement was observed on positron emission tomography. Patients presenting with back and leg pain should be considered for primary spinal epidural lymphoma, and the treatment should be planned accordingly since patients have good prognosis with early treatment.
\end{abstract}

Keywords: Primary spinal epidural lymphoma, thoracic spine, spinal cord compression, surgery, chemotherapy

\section{$\ddot{0} Z$}

Primer spinal epidural lenfomalar çok nadir görülen lezyonlardır. Omurilik basısı olması halinde cerrahi dekompresyon ve sonrasında kemoterapi bașlanması gereklidir. Kırk altı yaşında erkek hasta sırt ve bacak ağrısı, bacaklarda giderek artan güç kaybı ve yürüme güçlüğü yakınmalarıyla bașvurdu. Manyetik rezonans görüntülemede T-11 seviyesinde korda anterolateral ve posterior olarak basan ekstradural kitle lezyonu izlendi. Tümöral rezeksiyonla birlikte cerrahi dekompresyon yapıldı. Patoloji sonucu germinal merkez fenotipli B-hücreli lenfoma infiltrasyonu olarak geldi. Hematoloji kliniği tarafından kemoterapi bașlandı. Hasta minimal parapareziyle fizik tedaviye sevk edildi. Ameliyat sonrası pozitron emisyon tomografisinde patolojik tutulum gözlenmedi. Sırt ve bacak ağrısıyla birlikte bacaklarda güç kaybı ve yürüme güçlüğü olan hastalarda primer spinal epidural lenfoma tanısı göz önünde bulundurulmalı, hastaların tedaviye iyi yanıt vermesi nedeniyle erken teșhis ile tedavi iyi planlanmalıdır.

Anahtar Kelimeler: Primer spinal epidural lenfoma, thoracic vertebra, spinal kord basısı, cerrahi, kemoterapi

\section{Introduction}

Primary spinal epidural lymphomas are rarely seen. They are reported as $0.1 \%-6.5 \%$ of the lymphoma cases and $9 \%$ of spinal epidural tumours (1). Primary spinal epidural lymphomas are defined as type of lymphomas with no other disease site at the time of diagnosis (2). It is thought to arise from paraspinal lymphoid tissue with secondary involvement of the spinal cord (3). Thoracic spine is mostly involved with male predominance. Clinical features may include backpain, lower limb weakness, sensory deficit and urinary or anal sphincter function disturbance $(4,5)$.
Here, we present the case of a 46-year-old man with lower limb weakness because of a spinal extradural cord lesion which was diagnosed as germinal centre type of diffuse large B-cell lymphoma.

\section{Case Report}

A 46-year-old man was admitted to neurosurgery outpatient clinic with intense thoracic pain and difficulty in walking due to loss of strength in both legs that started a month ago. His medical history and family history were both unremarkable, except the proton pump inhibitor he was taking for gastritis.
Address for Correspondence/Yazıșma Adresi: Nuriye Güzin Özdemir MD, University of Health Sciences Turkey, İstanbul

Training and Research Hospital, Clinic of Neurosurgery, İstanbul, Turkey

Phone: +905453221262 E-mail: guzozdemir@yahoo.com ORCID ID: orcid.org/0000-0002-2702-4526

Cite this article as/Atıf: Özdemir NG, Baran Ö, Șahin ÖF, Akbaș F, Tan Köker H, Erdem Huq G. Primary Spinal Epidural Lymphoma: A Case Report. İstanbul Med J 2020; 21(Suppl 1): 32-38.
Received/Geliș Tarihi: 18.09.2020 Accepted/Kabul Tarihi: 10.10 .2020

(C) Copyright 2020 by the University of Health Sciences Turkey, Istanbul Training and Research Hospital/istanbul Medical Journal published by Galenos Publishing House.

(C) Telif Hakkı 2020 Sağlık Bilimleri Üniversitesi İstanbul Eğitim ve Araştırma Hastanesi/Istanbul Tıp Dergisi, Galenos Yayınevi tarafından basılmıștır. 
His neurologic examination demonstrated paraparesis of $4 / 5$. He had a sensory level of hypoesthesia at T-10. No abnormal reflex was detected and urinary and anal sphincter tonus was normal. The other systemic findings and laboratory results were found to be normal.

A magnetic resonance imaging (MRI) was ordered as the patient was thought to have a thoracic or thoracolumbar spinal involvement because of primary spinal tumour or metastasis. MRI showed an intraspinal extradural mass lesion iso-hypointense on T1-weighted imaging (T1WI) and iso-hyperintense on T2WI at T-11 level. The lesion was homogeneously enhanced and compressed medulla especially on the anterior aspect and extended posterolaterally (Figure $1 \mathrm{~A}-\mathrm{D}$ ) (Figure 1 A, B: Pre-operative MRI, Figure 1 C, D: Postoperative MRI).

Weakness of lower limbs progressed in a 2 weeks' period during his diagnostic investigation, and he could not walk without assistance.

The patient was hospitalised in our neurosurgery clinic, and surgery was planned to take a biopsy both for the diagnosis and the urgent need for decompression spinal surgery. He was operated, and medullary decompression was accomplished with T-11 laminectomy and tumoural resection on the right side, where the tumoural tissue was abundant, paying special attention not to pull the spinal cord. A grey-pink, firm lesion with the bone involvement was extracted and sent for pathological examination, which was reported as a diffuse large B-cell lymphoma (Figures 2-4). Immunochemistry report showed CD20 (+), CD23 (+), CD45 $(+)$, BCL-2 (-), BCL-6 (+), CD3 (-), CD5 (-), CD10 focal (+), CD56 (-), MUM$1(-)$, C-MYC (-) of neoplastic cells. Positivity of Ki-67 in nearly all large

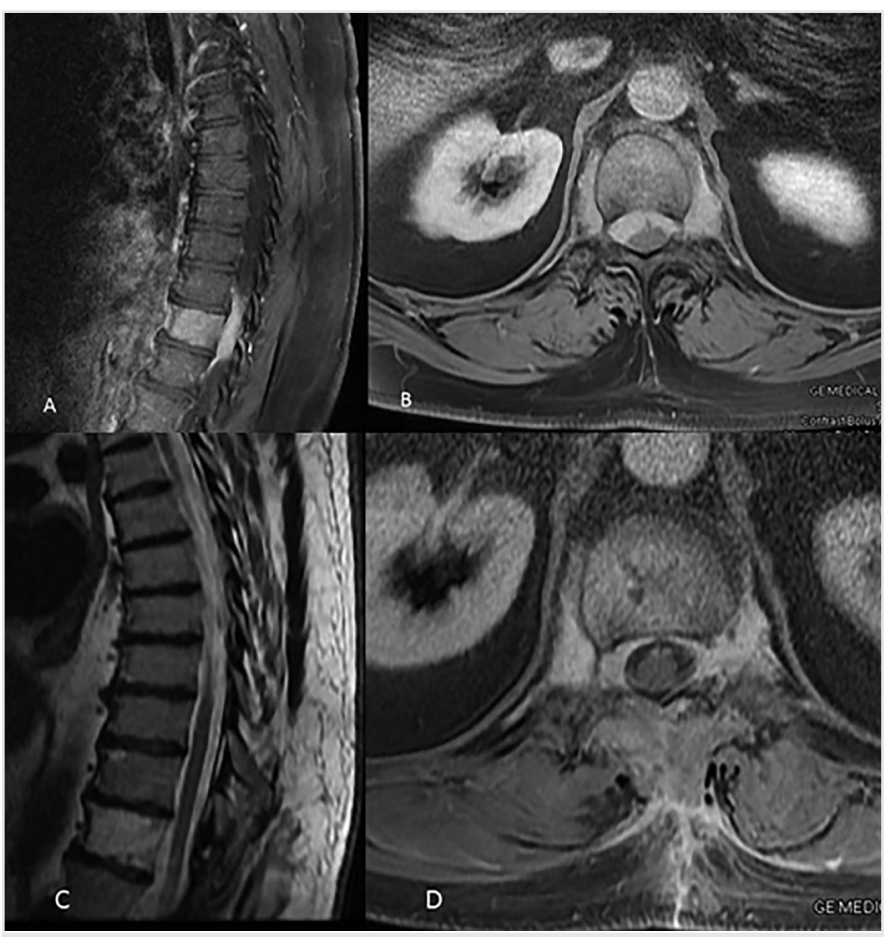

Figure 1. A, B: Sagittal T1-weighted (T1W) contrast magnetic resonance imaging (MRI) shows epidural mass compressing the spinal cord at T-11 level. Axial T1W contrast MRI shows lesion extending from anterolateral region posteriorly C, D: Postoperative sagittal and axial T1W contrast MRI showing the spinal cord decompression after tumour resection and chemotherapy tumour cells showed high proliferation index. The diagnosis was B-cell lymphoma infiltration with germinal centre phenotype.

The patient was investigated further for other possible sites of Iymphoma. No other primary site of lymphoma was revealed from the reports of whole body bone scintigraphy scan, single photon emission computed tomography (CT) and the positron emission tomography (PET), and the final diagnosis was a primary spine epidural lymphoma.

The patient quickly mobilised with little pain and was need of assistance during the early postoperative period. The patient was consulted with haematology clinic, and bone marrow biopsy was performed. The pathological result showed mild small B-cell proliferation and rare CD20 (+) large B-cells, normocellular bone marrow suboptimal for evaluation. Chemotherapy including rituximab, cyclophosphamide, doxorubicin and prednisolone (R-CHOP protocol) was initiated with the

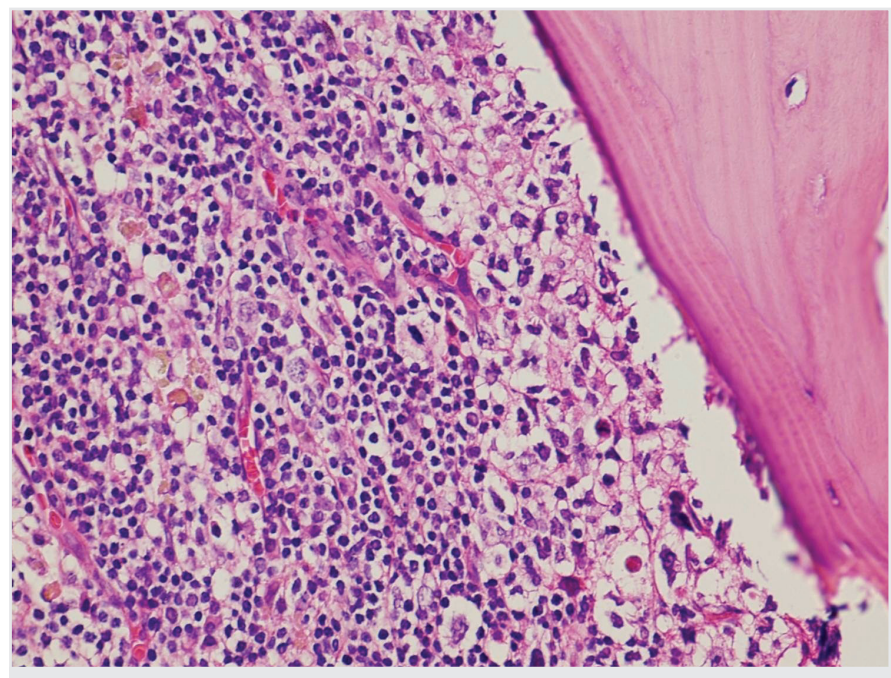

Figure 2. On the right side, bone trabeculae and at the adjacent area infiltration of the atypical lymphoid cells is observed. The infiltrative cells are irregularly bordered or lobulated lymphoid cells with clear cytoplasm and big nuclei. Lymphocytes are also observed at the distant areas of trabeculae (HEx200)

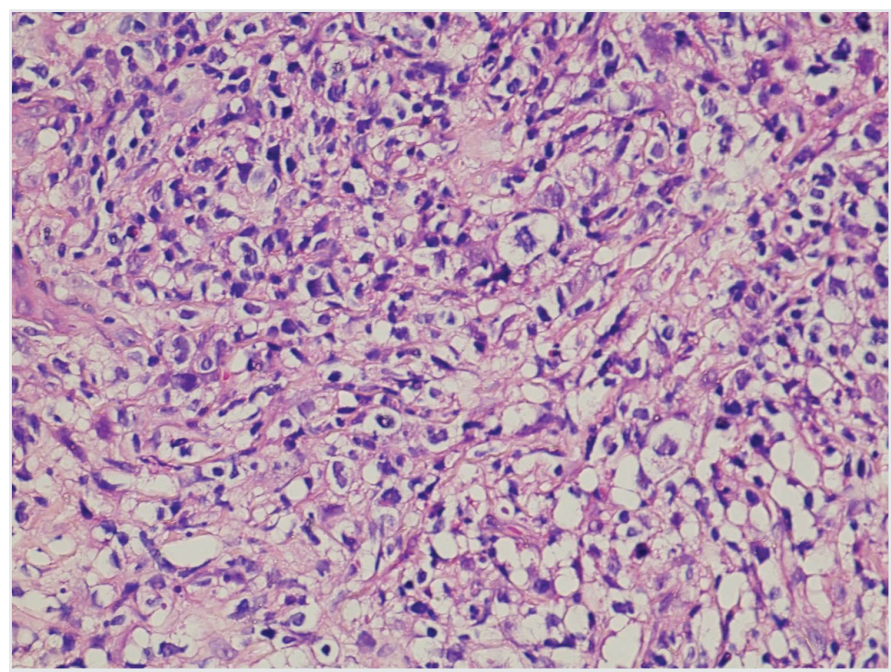

Figure 3. The area with large atypical lymphoid cells and diffuse infiltration (HEx200) 


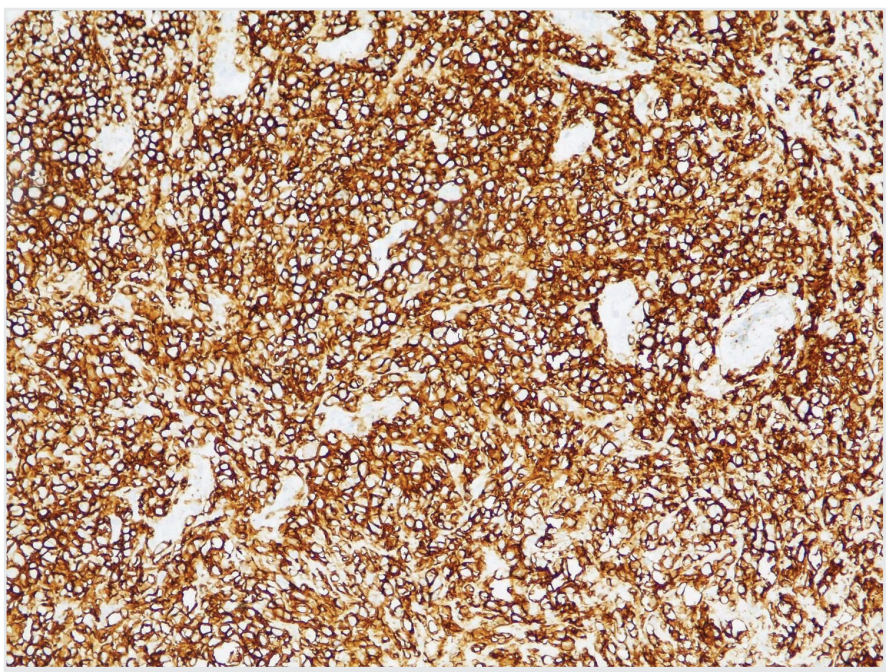

Figure 4. Lymphoid infiltration shows strong and diffuse staining with CD20 immunohistochemically (DABx200)

definitive diagnosis of B-cell lymphoma. Chemotherapy was completed to six cycles. The patient was administered high-dose methotrexate for the purpose of central nervous system (CNS) prophylaxis. PET-CT was observed to be fully responsive at the end of the treatment. After chemotherapy, he started to walk without assistance and MRI showed clearance of the tumoural tissue in the epidural region. After 2 years of follow-up period, presently, he is mobile, and has only complaint of minimal gonarthralgia, which relieves with physiotherapy.

The voluntary informed consent form was obtained from the patient.

\section{Discussion}

Extranodal non-Hodgkin lymphoma (NHL) comprises $24 \%-48 \%$ of all NHLs. Spinal extradural lymphomas account for $9 \%$ of all spinal epidural tumours and $0.9 \%$ of all extranodal NHLs (5). NHL of spinal epidural region is rarely seen and reported as $9 \%$ of all spinal epidural tumours (5-7). Subdural or intramedullary involvement has also been reported to be rare (8).

It is found to be more common in male than female patients with a ratio of $7: 2$. Age of presentation is in the fourth to seventh decade. Most common involvement is in the mid-thoracic spine (69\%), followed by lumbar (27\%) and cervical spine (4\%) (2,5,9-11). Differential diagnosis includes metastasis, primary bone tumours, multiple myeloma and infections (4).

Primary spinal epidural NHL diagnosis is made when all other system pathologies are excluded (3). We also excluded all other etiological possibilities in our case, and the diagnosis was made after the operation and biopsy evaluation.

The pathogenesis of primary spinal epidural lymphoma was explained by the role of chronic inflammatory process, chronic infection, autoimmune disease and the meningoepithelial component $(5,10)$. The theories about the origin are controversial. The lymphoma cells are thought to originate from lymphatic tissue along the venous plexus in the epidural space or the paravertebral lymphoid rests $(2,11)$. Antigenic stimulation with a transformation cascade was theorised as epidural tissue contains lymphoid cells. Other suggestions include the origination of these epidural tumours from paraspinal, vertebral and retroperitoneal tissues after entering through the intervertebral foramina $(9,12)$.

Histopathological examination of primary spinal epidural lymphoma shows atypical lymphoid cell proliferation. B-cell lymphoma is the most common type. Immunohistochemistry demonstrates tumour cell positivity for leukocyte common antigen and CD20 (13).

Spinal epidural lymphomas are generally diagnosed as B-cell lymphomas as in our case. Diffuse large B-cell lymphoma is the most common type (2), and it represents $30 \%$ of all NHLs. Spinal epidural lymphoma of this type is classified as germinal centre B-cell type or non-germinal centre B-cell type. First one is CD10 (+) or CD10 (-)/BCL-6 (+)/MUM-1 (-), and the second one is CD10 (-)/BCL-6 (-) or CD10 (-)/BCL-6 (+)/MUM-1 (-). Germinal centre B-cell type is more common in the spine compared to CNS $(5,14)$.

Presentation with a spinal cord compression is rarely seen among NHL patients, and it is reported as 5\%. Primary spinal lymphoma patients first complain about back or leg pain and difficulty in walking. Neurologic deficits as paraparesis, ataxic gait, sensory disturbance with possible urinary and bowel involvement occur later. Progression to lower limb weakness due to cord compression may be observed in a 2-week to 2-month period $(2,5,15)$.

MRI is a useful diagnostic tool to detect the cord compression and for surgical planning. However, first, systemic primary lymphoma should be excluded. Lesion is usually hypo-isointense on T1WI and iso-hyperintense on T2WI, however, T2WI may show low signal due to the variable density of tumour cells $(2,4)$. MRI appearance of the lesion was isointense on T1-weighted images and iso-hyperintense on T2WI with homogeneous enhancement in our case in accordance with the literature.

As an adjuvant technique, PET shows the tumour as an area with intense hyper-metabolic activity $(16,17)$.

Since NHL is very sensitive to radiotherapy and chemotherapy, surgery is considered in patients with one site involvement, in order to confirm the diagnosis and decide for the treatment options accordingly. Surgical decompression and biopsy provide the highest possible volume reduction. Thus, it is considered as the best modality in patients with spinal cord compression. Rapid progression of motor weakness, especially with loss of urinary anal sphincter control requires emergency decompression. Patients with spinal instability may require spinal stabilisation $(5,10)$. This approach also allows for histopathological diagnosis in a patient with no other known diagnosis related to the epidural lesion and expedites the planning of the chemotherapy and radiotherapy if needed.

Adjuvant therapy increases the disease-free survival period $(18,19)$. Intrathecal chemotherapy may be considered in individualised treatment (2). Chemotherapy, including cyclophosphamide, vincristine and prednisone, is recommended after the surgical decompression and pathological diagnosis. Radiotherapy at doses of $25 \mathrm{~Gy}$ may be given as an adjuvant treatment. 
Primary spinal epidural lymphoma should be considered in patients with spinal cord compression of extradural soft tissue lesion with or without bone involvement. The prognosis and functional recovery are relatively better for patients with spinal cord compression because of $\mathrm{NHL}$, and it is important to make a timely diagnosis before paraplegia occurs.

\section{Ethics}

Informed Consent: The voluntary informed consent form was obtained from the patient.

Peer-review: Externally peer-reviewed.

Authorship Contributions: Surgical and Medical Practices - N.G.Ö., Ö.B., Ö.F.S., F.A., H.T.K.; Concept - N.G.Ö.; Design - N.G.Ö., F.A.; Data Collection or Processing - N.G.Ö., Ö.B., Ö.F.S., G.E.H.; Analysis or Interpretation N.G.Ö., F.A.; Literature Search - N.G.Ö., Ö.B., Ö.F.S.; Writing - N.G.Ö., F.A.

Conflict of Interest: No conflict of interest was declared by the authors.

Financial Disclosure: The authors declared that this study received no financial support.

\section{References}

1. Cugati G, Singh M, Pande A, Ramamurthi R, Balasubramanyam M, Sethi SK, et al. Primary spinal epidural lymphomas. J Craniovertebr Junction Spine 2011; 2: 3-11.

2. Shu Y, Wang A, Yi L, Xu X, Yang W. Primary spinal epidural diffuselarge B-cell lymphoma with paraplegia as the first manifestation: a case report. Onco Targets Ther 2019; 12: 6497-501.

3. Moussaly E, Nazha B, Zaarour M, Atallah JP. Primary non-Hodgkin's lymphoma of the spine: A case report and literature review. World J Oncol 2015; 6: 459-63.

4. Zheng JS, Wang M, Wan S, Zhou YQ, Yan M, Chen QF, et al. Isolated primary nonHodgkin'slymphoma of the thoracic spine: a case report with a review of the literature. J Int Med Res 2010; 38: 1553-60.

5. Córdoba-Mosqueda ME, Guerra-Mora JR, Sánchez-Silva MC, Vicuña-González RM, Torre Al. Primary spinal epidural lymphoma as a cause of spontaneous spinal anterior syndrome: A case report and literature review. J Neurol Surg Rep 2017; 78: e1-4.

6. Cho HJ, Lee JB, Hur JW, Jin SW, Cho TH, Park JY. A rare case of malignant lymphoma occurred at spinal epidural space: A case report. Korean J Spine 2015; 12: 177-80.
7. Di Marco A, Campostrini F, Garusi GF. Non-Hodgkin lymphomas presenting with spinal epidural involvement. Acta Oncol 1989; 28: 485-8.

8. Vanneuville B, Janssens A, Lemmerling M, de Vlam K, Mielants H, Veys EM Non-Hodgkin's lymphoma presenting with spinal involvement. Ann Rheum Dis 2000; 59: $12-4$

9. Mally R, Sharma M, Khan S, Velho V. Primary lumbo-sacral spinal epidural non Hodgkin's Lymphoma: A case report and review of literature. Asian Spine J 2011; 5: 192-5.

10. Tsukada T, Ohno T, Tsuji K, Kita K, Kobayashi T, Deguchi K, et al. Primary epidural non-Hodgkin'slymphoma in clinical stage IEA presenting with paraplegia and showing complete recovery after combination therapy. Intern Med 1992; 31: 513-5.

11. Jagtap SA, Patil AS, Kesavdas C, Radhakrishnan N, Soni H, Satish KS. Primary spinal epidural diffuse large B-celllymphoma. Neurol India 2013; 61: 532-4.

12. Kim SK, Lee SH, Kim ES, Eoh W. DiffuseLarge B-Cell lymphoma mimicking schwannoma of lumbar spine. Korean J Spine 2016; 13: 71-3.

13. Xiong L, Liao LM, Ding JW, Zhang ZL, Liu AW, Huang L. Clinicopathologic characteristics and prognostic factors for primary spinal epidural lymphoma: report on 36 Chinese patients and review of the literature. BMC Cancer 2017; 17.

14. Arslan H, Yavuz A, Aycan A. Primary Spinal Lymphoma Masquerading as Meningioma: preoperative and postoperative magnetic resonance imaging findings. World Neurosurg 2018; 118: 86-7.

15. Luo CC. Spinal cord compression secondary to metastatic non-Hodgkin's Iymphoma: a case report. Arch Phys Med Rehabil 2005; 86: 332-4.

16. Popescu M, Popov V, Popescu G, Dobrea C, Sandu A, Grigorean VT, et al. Spinal involvement with spinal cord compression syndrome in hematological diseases. Rom J Morphol Embryol 2012; 53: 1069-72.

17. Tang Y, Yang X, Xiao J, Liu K, Yan W, Song D, et al. Clinical outcomes of treatment for spinal cord compression due to primary non-Hodgkin lymphoma. Spine J 2013; 13: 641-50.

18. Monnard V, Sun A, Epelbaum R, Poortmans P, Miller RC, Verschueren T, et al. Primary spinal epidural lymphoma: patients' profile, outcome, and prognostic factors: a multicenter Rare Cancer Network study. Int J Radiat Oncol Biol Phys 2006; 65: 817-23.

19. Mkandawire N. Primary spinal cord epidural non-Hodgkin's lymphoma as cause of paraplegia: report of 2 cases. Malawi Med J 2003; 15: 72-5. 